\title{
Editorial
}

\author{
Valquíria Ferreira Dutra ${ }^{1,4}$, Tatiana Tavares Carrijo ${ }^{2} \&$ Anderson Alves-Araújo $^{3}$
}

\section{Projeto Flora do Espírito Santo: revelando a flora capixaba}

Espírito Santo ranks as the $7^{\text {th }}$ Brazilian state in terms of diversity of angiosperms, ferns, and lycophytes (Dutra et al. 2015; Prado et al. 2015). This comes as a result of its variety of environments whose geographic formations extend from sea level to elevations of up to 2,892 $\mathrm{m}$. Historically, the state's development was impeded by royal decree as a way to prevent the smuggling of gold, which delayed its economic growth by at least 300 years compared to other captaincies (Nascimento 2016). This delay was also reflected in the state's scientific development. Research institutes and universities in existence today date back to only the second half of the $20^{\text {th }}$ century.

This background explains the late start of scientific investigations into the flora of Espírito Santo since other Brazilian states had started cataloging theirs in the last century (e.g., Santa Catarina, which conducted the first studies of Flora Ilustrada Catarinense begun in 1951, by Raulino Reitz; São Paulo, with the project Flora Fanerogâmica do Estado de São Paulo started in 1994; and Bahia, where the Flora da Bahia project began in 1999).

The real possibility of starting these investigations came only in 2008, after carrying out a diagnosis of collections deposited in different Brazilian herbaria, collected by Brazilian and foreign naturalists and taxonomists traveling through Espírito Santo. The Flora do Espírito Santo project, which aims to list, describe, produce iconographic images, and identify the distribution of species that occur in the state, is the result of meticulous and carefully considered work, discussed by researchers engaged in disseminating scientific information about Espírito Santo's biodiversity.

More than 80 researchers from 23 national and international institutions are currently engaged in this endeavor to monograph the Espírito Santo flora and fungi, thus contributing to the body of knowledge of Brazilian biodiversity and the training of professionals in plant taxonomy.

An important product for the knowledge of the Flora of Espírito Santo was the 2015 publication of the manuscript "Angiosperm Checklist of Espírito Santo: using electronic tools to improve the knowledge of an Atlantic Forest biodiversity hotspot", based on information available in virtual herbaria and on the Flora do Brasil website. This manuscript listed 6,364 species, 1,390 genera, and 180 families of angiosperms in the Espírito Santo (Dutra et al. 2015). Based on that list, the Rodriguésia Journal published a special volume in 2017, dedicated to studies of the flora of Espírito Santo, constituting a reference for that state's flora in terms of its floristic-taxonomic treatment of 21 families, 60 genera, and 290 species of lichen, ferns, and angiosperms, 21 of which are endemic to the state (Carrijo \& Mansano 2017).

In this second special volume, we present the treatment for 24 families, 85 genera, and 313 species, of which 31 are endemic to Espírito Santo, and 27 represent new occurrences. Seven new species to science are also published. With the publication of this volume, morphological descriptions of $15 \%$ of the families, $11 \%$ of the genera, and $12 \%$ of the species of angiosperms mentioned for Espírito Santo have been completed.

\footnotetext{
${ }^{1}$ Universidade Federal do Espírito Santo, Centro de Ciências Humanas e Naturais, Depto. Ciências Biológicas, Vitória, ES, Brasil. ORCID: <https://orcid. org/0000-0003-1547-1377>.

${ }^{2}$ Universidade Federal do Espírito Santo, Centro de Ciências Exatas, Naturais e da Saúde, Depto. Biologia, Vitória, ES, Brasil. ORCID: <https://orcid.org/00000002-8366-0738>.

${ }^{3}$ Universidade Federal da Bahia, Instituto de Biologia, Salvador, BA, Brasil. ORCID: < https://orcid.org/0000-0001-5810-5145>.

${ }^{4}$ Author for correspondence: valquiria.dutra@ufes.br
} 
We would like to thank the Rodriguésia editorial board, who worked with great skill and enthusiasm to publish this volume, as well as the area editors and reviewers who donated their time and knowledge to significantly contribute to the quality of the work presented here. We would also like to express our most sincere thanks to the authors who, proactively, have greatly contributed to shedding light on Espírito Santo's biodiversity.

This second volume of Flora do Espírito Santo takes shape in the midst of numerous and important socio-political-environmental discussions throughout the world, where one of the main goals is the protection and maintenance of biodiversity. This is yet another example of where information generated from local and regional studies can build solid bases for creating useful tools for resource management and maintenance of environmental public policies on a national scale. The work is ongoing and, therefore, we hope that more studies dedicated to the flora and fungi of Espírito Santo can constitute special volumes in the future.

\section{References}

Carrijo T \& Mansano VF (2017) Editorial. Rodriguésia 68: 1504. DOI: 10.1590/2175-7860201768500

Dutra VF, Alves-Araújo A \& Carrijo TT (2015) Angiosperm checklist of Espírito Santo: using electronic tools to improve the knowledge of an Atlantic Forest biodiversity hotspot. Rodriguésia 66: 1145-1152. DOI: 10.1590/21757860201566414

Nascimento RC (2016) A narrativa histórica da superação do atraso: um desafio historiográfico do Espírito Santo. Tese de Doutorado. Universidade Federal do Espírito Santo, Vitória. 289p.

Prado J, Sylvestre LS, Labiak PH, Windisch PG, Salino A, Barros ICL, Hirai RY, Almeida TE, Santiago ACP, KielingRubio MA, Pereira AFN, Øllgaard B, Ramos CGV, Mickel JT, Dittrich VAO, Mynssen CM, Schwartsburd PB, Condack JPS, Pereira JBS \& Matos FB (2015) Diversity of ferns and lycophytes in Brazil. Rodriguésia 66: 10731083. DOI: $10.1590 / 2175-7860201566410$ 